\title{
Benefit - Cost Analysis of Onion Producer in Sagar District of Madhya Pradesh, India
}

\author{
Shampi Jain* and Jayant Kumar Gupta \\ Department of Agricultural Economics/Transfer of Technology, Mahatma Gandhi Chitrakoot \\ Gramodaya Vishwavidyalaya, Chitrakoot (MP), India \\ *Corresponding author
}

\begin{abstract}
A B S T R A C T
\end{abstract}

\begin{tabular}{l} 
Ke y w or d s \\
$\begin{array}{l}\text { Variable Cost, } \\
\text { Benefit, Fixed cost, } \\
\text { Production, Benefit }\end{array}$ \\
\hline Article Info \\
$\begin{array}{l}\text { Accepted: } \\
\text { 10 December } 2017 \\
\text { Available Online: } \\
\text { 10 January } 2018\end{array}$ \\
\hline
\end{tabular}

A comparative study was conducted for benefit - cost ratio analysis of small, medium and large scale onion producer in Sagar district of Madhya Pradesh, India. In this study almost all type of farmers were involved in different activities where onion farming was a major occupation i.e. $70 \%$ large and 55\% medium type of farmers. The maximum operational cost was found to be Rs. 5950.19 for large type farmers and was from family labour. The minimum per hectare operational cost was found from bullock labour for small type farmers i.e. Rs. 1221.67. In case of material cost, the highest cost was involved in plant protection i.e. Rs. 6261.30 for large type of farmers. The highest fixed cost was recorded from rental value of owned land for large scale farmers i.e. Rs. 27066.67. The total cost involved for onion production was maximum of large type farmers i.e. Rs. 73581.04. The net return was found maximum (Rs. 88818.96) for large type of farmers whereas minimum (Rs. 65844.34) was for small type of farmers according to availability of land area utilized for onion cultivation. The Benefit - Cost ratio were found maximum (7.48: 2) for small type of farmers whereas large type of farmers hold minimum (6.84: 2) cost - benefit ratio.

\section{Introduction}

The area of onion research has attracted considerable interest among the researchers across the world. Many academicians, institutions and researchers in the country have conducted important studies in various dimensions of onion research, such as production of onion production economics, marketing, breeding, products and price mechanisms, marketing channels etc. India is the second largest producer of onion in the world, but far behind of many countries in terms of productivity. Maharashtra is a pioneer state in onion production contributing $25 \%$ of country's onion. Ghulghule and Thomre (2009) reported 18.89 lakh hectare areas for onion production with annual production of 282.23 lakh tonnes and its productivity is 15 tonnes per hectare. In India it occupies an area of 3.95 lakh hectare with annual production of 42.33 lakh tonnes which area and to about 21per cent of the world area, and 15 per cent of world production (Barakade et al., 2011) classified the cultivators into three categories i.e. small (below 2 ha.), medium (2-4 ha.) and large (above 4 ha.) based on land holding size of the farmers in 
Satara district of Maharashtra. Gade AND Lawande (2012) observed that onion (Allium cepa L.) is among the most important horticultural crops grown worldwide for its culinary preparation sand spicing food dishes. He collected data from 100 farmers, 10 each from 10 villages from Ahmednagar and Pune districts. He found that the crop damage due to erratic rainfall at the time of harvesting of kharif onion and nursery preparation of rabi onion was the major constraint faced by $73 \%$ farmers.

Reddy et al., (2012) reported the magnitude of regression coefficient revealed that an increase in market arrivals by a MT in a month led to an increase in prices by Rs.6.00/MT and Rs. 0.40/MT in Bangalore and Delhi markets respectively. Pawar (1998) concluded that small farmers sold maximum of their produce in the local market i.e. weekly market and to village vender and received less price as compared to wholesale market and as against other size groups. A reverse result was found in the case of large size groups i.e. they sold maximum of their produce of selection farm products in wholesale market. Jerry et al., (2004) studied onion cost and return estimates at long-run continued success of New Mexico's commercial onion crop will, as always, depend upon the profitability of the crop in any or all of its various forms.

Chakraborty and Sankar (2005) concluded that onion cultivation was highly profitable vegetable as compared to the other vegetable. Safraz et al., (2008) observed that the cost of seedlings i.e. Rs.3200/-per acre followed by Rs.2400/- on farm yard manure (FYM) and Rs.1600/- on land preparation per acre. Majority (93\%) of the respondents sold their onion to beeper and remaining took their produce to wholesale market of Muzaffarabad; but results indicated that the producer who sold his produce through wholesale market fetched more profit than selling through middleman. Barakade et al., (2011) reported that the present study was carried out in 201011 to determine the economics of onion marketing on onion is Satara district, at least 175 countries grow onions. India is second largest onion growing country in the world. The total area under cultivation of onion crop is 84600 thousands hectares with total production of metric tonnes during the year 2008 -09. Haque et al., (2011) reported Total of 150 onion farmers taking 50 farmers from each area were selected randomly. The yield of onion was found 9869 metric tons per hectare.

Kodge (2013) reported that in the year 2012 2013 onion production was 116.54 lakh tones out of which 4.7.63 lakh tones from Maharashtra, 25.23 lakh tonnes from Karnataka 21.50 lakh tonnes from M.P. and 15.14 lakh tonnes from Andhra Pradesh. The production of onion in India was 151.17 lakh tonnes 2012-2013. Bloch et al., (2014) done random sampling 60 farmers and found 21-30 year age group was mainly involved in onion farming. 25.00 per cent onion farmers were Primary level of education; the 33.33 per cent were middle, 16.66 per cent of matriculation and 3.33 per cent farmers of the bachelor/master education in the study area. He also found total cost of production of Rs. 75050.00 during study this included Rs.18100.00, Rs.9600.00, Rs.28510.00 and Rs.18840.00 on a fixed cost, labour costs, marketing costs respectively on capital inputs. Thus the onion growers in Aware Baluchistan area obtained per acre 144 in mound on an average. And revenue per acre earned of Rs. 172800.00 that obtained by the growers of onion. On an average per acre earned during the study, Rs.97750.00 on net income, Rs.172800.00 on gross income and Rs.75050.00 on to telex pedicure in the Awaran Baluchistan. Therefore they availed input, output ratio of 1:1.30 from onion growing in the study area. 
Kumar (2016) found that the average cost per hectare of red onion was Rs 1.35 lakh for marginal farmers, 1.28 lakh for small farmers, around Rs 1 lakh for medium farmers and Rs 67 thousand in the case of large farmers thus establishing clearly inverse relation with farm size. SFAC (2015) reported that India harvest maximum onion in January i.e. $32 \%$ more than other months. In India Rabi production is expected to be approximately 95 lakh ton. As per IBIS (International Business Information Services), approximately 78383 tons of processed and fresh onion has been exported in month of January 2015 compared to previous month export of 34081 tons. In Karnataka, total Rabi area is approximately 16676 ha. As on 27.1.2015 approximately 18145 ha of area is sown compared to last year area of 23844 ha. Lorkspur and Kulkarni (2014) reported that onion farmers require 70.25 man hours for complete cycle in one hectare.

The total cost incurred for labour was Rs. 31240.2 per hectare and found the net returns of Rs.93278.43/ha. The main objective of this study was to analyse benefit - cost ratio of onion production in Sagar district of Madhya Pradesh.

\section{Materials and Methods}

\section{Selection of study area}

Sagar district of Madhya Pradesh was selected purposively as having remarkable area (2179 ha) of onion in the district of the state.

\section{Selection of respondent}

After selection of study area, a list of onion growers ware prepared and further categories according to their size of holding and grouped into Small (1.0 to 2.0 ha) Medium (2.01 to 4.0 ha) and Large (above 4.01 ha). From each size group of holding, 20 farmers were selected randomly. Thus total 60 farmers were considered for detail investigation to fulfill the stated objectives.

\section{Collection of data}

The study is based on both primary and secondary data. The primary data was collected from the selected respondents with the help of pre-tested interview schedule by the personal interview method and secondary data was collected from Madhya Pradesh agriculture statistics, land record office, annual districts statistics and other published and unpublished reports.

\section{Method of analysis}

The collected data were tabulated, processed and analyzed to estimate the cost and return of onion

Benefit cost ratio $=\frac{\text { Gross Income }}{\text { Gross Expenses }}$

\section{Results and Discussion}

In this study almost all type of farmers were involved in different activities where onion farming was a major occupation i.e. 70\% large and $55 \%$ medium type of farmers. In case of small farmers onion producer was only $30 \%$. Larger type farmers having average family size of 7 no. had maximum educational status i.e. degree holder (10\%). $100 \%$ and $70 \%$ household leads by male in small and large type farmers respectively (Table 1). The maximum area of irrigated and non-irrigated land i.e. 25.60 ha and 5.35 ha which were holded by large type of farms and minimum irrigated and non-irrigated land was 1.61 ha and 0.05 ha respectively belongs to small type of farmers. 90\%, 54\% and 65\% land were found to be get utilized for cultivation by small, medium and large type of farmers respectively (Table 2). 


\section{Selected respondents of the study area}

\begin{tabular}{|c|c|c|c|}
\hline District & Block & Village & Selected Respondents \\
\hline Sagar & Banda & Piduruwa & 20 \\
& & Patari & 20 \\
& & Sagoriya & 20 \\
\hline & Total Sample Size & & 60 \\
\hline
\end{tabular}

Table.1 Socio-economic Status of sample onion Growers

\begin{tabular}{|l|c|c|c|}
\hline Indicators & Small & Medium & Large \\
\hline Age (years) & 46 & 45 & 54 \\
\hline Main Occupation (\%) & \multicolumn{3}{|c|}{} \\
\hline Onion farming & 30.00 & 55.00 & 70.00 \\
\hline Dairy & 5.00 & 5.00 & 5.00 \\
\hline Own Business & 45.00 & 30.00 & 15.00 \\
\hline Others & 20.00 & 10.00 & 10.00 \\
\hline Education Status (\%) & 20.00 & 15.00 & 50.00 \\
\hline Primary & 35.00 & 75.00 & 0.00 \\
\hline Middle & 25.00 & 10.00 & 40.00 \\
\hline Matric & 20.00 & 0.00 & 0.00 \\
\hline Secondary & 0.00 & 0.00 & 10.00 \\
\hline Degree & & & \\
\hline Average Family Size (no) & 2 & 2 & 5 \\
\hline Male & 1 & 2 & 2 \\
\hline Female & & & \\
\hline Social Groups & 15 & 40 & 40 \\
\hline General & 5 & 5 & 15 \\
\hline SC & 70 & 50 & 35 \\
\hline OBC & 10 & 5 & 10 \\
\hline ST & & & \\
\hline Head of household (\%) & 100 & 85 & 70 \\
\hline Male & 0 & 15 & 30 \\
\hline Female & & & \\
\hline & & & \\
\hline
\end{tabular}

Table.2 Land ownership pattern on average sample Onion Growers (ha.)

\begin{tabular}{|l|c|c|c|}
\hline \multicolumn{1}{|c|}{ Indicators } & Small & Medium & Large \\
\hline Total owned land & \multicolumn{3}{c|}{} \\
\hline Irrigated & 1.61 & 2.81 & 25.60 \\
\hline Un-irrigated & 0.05 & 0.95 & 5.35 \\
\hline Area under onion cultivation & 1.50 & 2.00 & 20.00 \\
\hline Irrigated & 0.00 & 0.00 & 0.00 \\
\hline Un-irrigated
\end{tabular}


Table.3 Per ha cost (Rs.) of onion cultivation for selected farmers

\begin{tabular}{|c|c|c|c|c|}
\hline \multirow{2}{*}{$\begin{array}{l}\text { S. } \\
\text { No. }\end{array}$} & \multirow{2}{*}{ Particulars } & \multicolumn{3}{|c|}{ Farm Size } \\
\hline & & Small & Medium & Large \\
\hline A & Operational Cost & 12628.75 & 14752.65 & 16629.67 \\
\hline 1 & Imputed value of family labour & 5097.50 & 5921.56 & 5950.19 \\
\hline 2 & Hired Human labour & 4202.50 & 4540.90 & 5948.30 \\
\hline 3 & Bullock labour & 1221.67 & 1427.45 & 1720.43 \\
\hline 4 & Machine power & 2107.08 & 2862.74 & 3010.75 \\
\hline$\overline{\mathbf{B}}$ & Material Cost & 15506.14 & 19489.84 & 22417.67 \\
\hline 1 & Seed & 3662.03 & 4023.52 & 4612.20 \\
\hline 2 & Manures and fertilizers & 1450.76 & 1950.54 & 2236.20 \\
\hline 3 & Plant Protection & 3251.20 & 5431.44 & 6261.30 \\
\hline 4 & $\begin{array}{l}\text { Irrigation charges (by tube well Diesel + } \\
\text { electric) }\end{array}$ & 3910.05 & 4350.00 & 5100.00 \\
\hline 5 & Interest on working capital @6\% for season & 1432.107 & 1734.337 & 2007.973 \\
\hline 6 & Transportation & 1800.00 & 2000.00 & 2200.00 \\
\hline C & Fixed Cost & 22529.63 & 26413.80 & 29852.49 \\
\hline 1 & Rental value of owned land & 20000.00 & 23741.67 & 27066.67 \\
\hline 2 & Land revenue & 50.00 & 50.00 & 50.00 \\
\hline 3 & $\begin{array}{l}\text { Depreciation and maintenance of } \\
\text { implements and machinery }\end{array}$ & 2213.17 & 2269.03 & 2327.03 \\
\hline 4 & Interest on owned fixed capital & 266.46 & 353.10 & 408.79 \\
\hline \multicolumn{2}{|c|}{ Total cost } & 50664.52 & 60656.29 & 68899.83 \\
\hline
\end{tabular}

Table.4 Cost of onion cultivation (Rs/ha)

\begin{tabular}{|l|c|c|c|}
\hline Cost Involved & Small & Medium & Large \\
\hline Operational cost & 12628.75 & 14752.65 & 16629.67 \\
\hline Material Cost & 15506.14 & 19489.84 & 22417.67 \\
\hline Fixed cost & 22529.63 & 26413.80 & 29852.49 \\
\hline Total Cost & $\mathbf{5 0 6 6 4 . 5 2}$ & $\mathbf{6 0 6 5 6 . 2 9}$ & $\mathbf{6 8 8 9 9 . 8 3}$ \\
\hline
\end{tabular}

Table.5 Gross income for onion production

\begin{tabular}{|l|c|c|c|}
\hline Particular & Small & Medium & Large \\
\hline Total yield (q/ha) & 160 & 185 & 203 \\
\hline Price received per quintal (Rs) & 1500 & 1500 & 1500 \\
\hline Value of main product (Rs./ha.) & 240000 & 277500 & 304500 \\
\hline $\begin{array}{l}\text { Total area under onion cultivation } \\
\text { (ha.) }\end{array}$ & 1.5 & 2.0 & 20.0 \\
\hline Gross return (Rs) & 360000 & 555000 & 6090000 \\
\hline Net returns over total cost (Rs.) & 65844.34 & 77635.86 & 88818.96 \\
\hline
\end{tabular}


Table.6 Cost - Benefit analysis of onion production for all type of onion growers

\begin{tabular}{|l|l|l|l|l|l|}
\multicolumn{1}{|c|}{ Particulars } & $\begin{array}{c}\text { Cost Involved } \\
\text { Per ha. (Rs.) }\end{array}$ & $\begin{array}{c}\text { Total Cost } \\
\text { Involved } \\
\text { (Rs.) }\end{array}$ & $\begin{array}{c}\text { Gross } \\
\text { Return } \\
\text { (Rs.) }\end{array}$ & $\begin{array}{c}\text { Net } \\
\text { Benefit } \\
\text { (Rs.) }\end{array}$ & $\begin{array}{c}\text { Cost- } \\
\text { Benefit } \\
\text { Ratio }\end{array}$ \\
\hline Small & 50664.52 & 75996.78 & 360000 & 284003.22 & $7.48: 2$ \\
\hline Medium & 60656.29 & 121312.58 & 555000 & 433687.42 & $7.02: 2$ \\
\hline Large & 68899.83 & 1377996.60 & 6090000 & 4712003.4 & $6.84: 2$ \\
\hline
\end{tabular}

Fig.1 Cost of onion production (Rs. / Ha.)

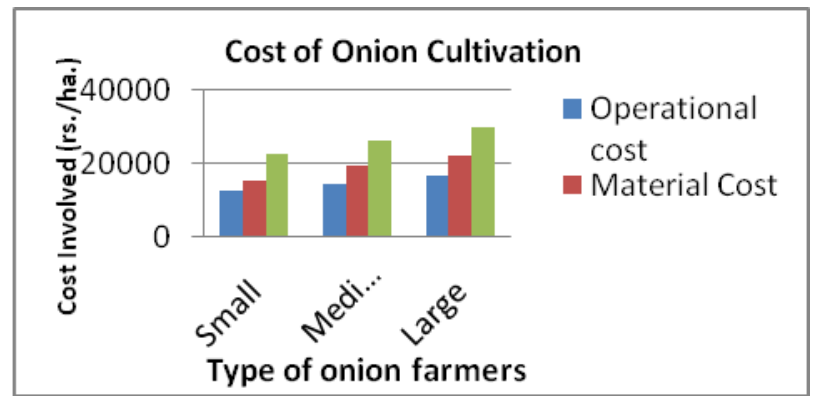

The maximum per hectare operational cost was found to be Rs. 5950.19 for large type farmers and was mainly from family labour.

Due to large land area they had to work daily for de-weeding, manual ploughing of surface soil. The minimum operational cost was found from bullock labour for small type farmers i.e. Rs. 1221.67. In case of material cost, the highest cost was involved in plant protection i.e. Rs. 6261.30 for large type of farmers. Poaching was the major hazardous problem found in farm area of large type of farmers. To overcome these problems they were use to do fencing for protection. The highest fixed cost was recorded from rental value of owned land for large scale farmers i.e. Rs. 27066.67. The total cost involved for onion production was maximum of large type farmers i.e. Rs. 73581.04 (table 3 \& 4 , Fig 1)). The net return were found maximum (Rs. 88818.96) for large type of farmers whereas minimum (Rs. 65844.34) was for small type of farmers according to availability of land area utilized for onion cultivation. The Benefit Cost ratio were found maximum (7.48: 2) for small type of farmers whereas large type of farmers hold minimum (6.84: 2) benefit - cost ratio (Table 5 and 6). By getting this type of result we can say that there is an inverse relationship between net benefit and benefit cost ratio. The type of farmers who were having small land area have better benefit - cost ratio because they can manage their all the needs and requirement for onion cultivation in better way within less involvement of cost than the farmers having large area. This result show that farm management practice is very important factor for better production of onion which is not up to the mark in large type of farmers in Satna district of Madhya Pradesh.

\section{Acknowledgement}

Authors have sincere gratitude to dean Dr. Arup Kumar Gupta for providing me such type of facility to perform my research work, Dr. Jayant Kumar Gupta for guiding us in each and every hard moment during my research work, all the teaching and non-teaching staff of college for supporting us.

\section{References}

Baloch, Ahmed Rameez; Ullah, Sana; Khan, Shahbaz; Noor, Hafeez Ahmed; 
Shambeer, Bashri Waseeem; Bakhsh Allah and Jehangeer, 2014. Economics Analysis of onion (Alicum cepa L.)" production and Marketing in District Awarn, Balochislan. Journal of Economics and Sustainable Development, 5 (24), paper ISSU 2222-2855 (online).

Barakade, A.J., Lokhande, T.N., and Todkari, G.U., 2011. Economics of onion cultivation and it's marketing pattern in Satara district of Maharashtra, International Journal of Agriculture Sciences, 3 (3), 2011, PP-110-117.

Chakraborty, Kiran Sankar, 2005. Marketing Costs and Margins of Agricultural Produce in Tripura, A National Level Quarterly Journal on Agricultural Marketing Directorate of Marketing \& Inspection, Ministry of Agriculture Deptt. of Agriculture \& Co-operation, Government of India, April-June, 2005 Vol.- XLVIII, No. : 1, I.S.S.N.—00021555

Gadge, S.S. and Lawande, 2012. Crop damage due to climatic change: A major Constraint in onion farming, Indian Research Journal of Extension Education Special Issue, Vol. II.

Ghulghule; J.N. and Thomore A.P., 2009. Profitability of Kharif onion (Allium cepa Linn) production, The Asian Journal of Horticulture, 4(1): 86-88.

Haqure, M.A., Monayem, M.A., Mach, Hossan S., Rahman, M.S. and Moniruzzaman, 2011. Profitability of onion cultivation in some selected Areas of Bangladesh, Journal Agril. Res. 36 (3); 427-435.

Jerry, M. Hawkes, James, D. Libbin, Hollie, Hughes and Brandon Jones, 2004. Onion
Cost and Return Estimates, Cooperative Extension Service Circular, 603.

Kodge vasant Baburao, 2013. Onion marketing in India: A case study of Maharashtra, Research Matrix International Journal, Vol-1.

Kumar, Parmod, 2016. Price difference in wholesale price Retail price and price Reutilize by Farmers for onion and grapes in Karnataka, Agricultural Development and Rural Transformation Centre Institute for Social and Economic Change Bangalore- 560072 Research Report February ADRTC/168.

Lokspur, Someer and Kulkarni, G.N., 2014. Economics production of vegetable in Belgaum District in Kranataka, International Research Journal of Agriculture Economics and statistic, Vol5.

Pawar, N.D., 1998. Channels and price spread of selected farm products in Marathwada Region of Maharashtra, Agriculture Marketing, 41 (3): 7-8

Raddy, B.S., Dikshit, A.K., Chandrashekhar, S.M. and Manohar N.S., 2012. Price trend and integration of wholesale Market of onion in metro cities of India, Journal of Economics and Sustainable Development, 3(7): 2222-2855.

Safraz, Ahmed; Chohan, T.Z. and Saddozai, K.N., 2008. An investigation into cost and Revenue of onion production in Azad Jammu Kashmir, Sarhad Journal Agric., 24(4).

SFAC 2015. Onion potato market intelligence system, Small Farmer Agribusiness consortium, February, monthly report, Vol. 33.

\section{How to cite this article:}

Shampi Jain and Jayant Kumar Gupta. 2018. Benefit - Cost Analysis of Onion Producer in Sagar District of Madhya Pradesh, India. Int.J.Curr.Microbiol.App.Sci. 7(01): 894-900. doi: https://doi.org/10.20546/ijcmas.2018.701.109 